\title{
Endocrine cells and nerve ganglia of the small intestine of the Opossum Didelphis aurita Wied-Neuwied, 1826 (Mammalia: Didelphidae)
}

\author{
GLÁUCIA M. FREITAS-RIBEIRO ${ }^{1 *}$, CLÁUdIO C. FONSECA ${ }^{2}$, SIRLENE S.R. SARTORI ${ }^{4}$, \\ ALAN LOURES-RIBEIRO ${ }^{3}$ and CLÓVIS A. NEVES ${ }^{5}$ \\ ${ }^{1}$ Departamento de Biologia Molecular, CCEN, Cidade Universitária, Castelo Branco, \\ Universidade Federal da Paraíba, 58051-900 João Pessoa, PB, Brasil \\ ${ }^{2}$ Departamento de Veterinária, Campus Universitário, Universidade Federal de Viçosa, \\ Avenida Peter Henry Rolfs, s/n, 36570-000 Viçosa, MG, Brasil \\ ${ }^{3}$ Departamento de Sistemática e Ecologia, CCEN, Cidade Universitária, Castelo Branco, \\ Universidade Federal da Paraíba, 58051-900 João Pessoa, PB, Brasil \\ ${ }^{4}$ Departamento de Biologia Animal, Campus Universitário, Universidade Federal de Viçosa, \\ Avenida Peter Henry Rolfs, s/n, 36570-000 Viçosa, MG, Brasil \\ ${ }^{5}$ Departamento de Biologia Geral, Campus Universitário, Universidade Federal de Viçosa, \\ Avenida Peter Henry Rolfs, s/n, 36570-000 Viçosa, MG, Brasil
}

Manuscript received on June 7, 2010; accepted for publication on March 22, 2011

\begin{abstract}
The nervous and endocrine systems jointly control intestinal movements, secretions of their glands and also participate of the processes of nutrient digestion and absorption. Therefore, the central objective of this study was to verify the existence of a possible relationship between the number of nervous cells and ganglia of the submucosal and myenteric plexuses and the number of endocrine cells in the small intestine of adult $D$. aurita. The utilized staining techniques were Grimelius, modified Masson-Fontana, direct immunoperoxidase and H-E. Argyrophillic, argentaffin and insulin immunoreactive endocrine cells do not numerically vary between the initial, mid and final regions of the duodenum, jejunum and ileum $(P>0.05)$, except for argyrophillic cells in the jejunum $(P>0.05)$. No numerical relationship has yet been verified between the number of nerve ganglia and endocrine cells, and also between nervous and endocrine cells. We recommended the use of new immunohistochemical techniques to confirm the numerical correlation between the nervous and endocrine systems in the small intestine. The morphology and distribution of endocrine cells and the nerve ganglia studied were similar to those encountered in eutherian mammals.
\end{abstract}

Key words: argyrophillic cells, argentaffin cells, endocrine cells, ganglia, insulin.

\section{INTRODUCTION}

Marsupials of the genus Didelphis have already been utilized as a model in studies of enteroendocrine cells, aiding in aspects of their identification,

Correspondence to: Gláucia M. Freitas-Ribeiro

Email: glauciamfr@yahoo.com.br

*Financial support CNPq distribution, quantification (Krause et al. 1985, Barbosa et al. 1987, Takagi et al. 1990) and ontogenesis (Krause et al. 1989, Fonseca et al. 2002).

Enteroendocrine cells can be classified as argyrophillic or argentaffin by their capacity to retain and reduce silver salts in both open and closed cells, in accordance with the apical communication 
with the lumen and in hormone producing cells (insulin, secretin, somatostatin and others), principally based on the characteristics and content of their secreting granules (Grimelius and Wilander 1980, Polak et al. 1993, Santos and Zucoloto 1996).

Insulin producing endocrine cells have been immunolocalized in extrapancreatic regions, as in the prostate, nephron, central nervous system, retina and intestine (Coutinho et al. 1985, Stahler et al. 1988, Bendayan and Park 1991, Devaskar et al. 2002, Meimaridis et al. 2003). It is speculated that in the intestine, insulin may precipitate glucose not absorbed from the digestive residue, reducing peristalsis to provide sufficient time for a more efficient absorption as well as control secretion of other peptides of the same cell or neighboring cells, mortality and intestinal absorption (Kendzierski et al. 2000).

In addition to the endocrine control of the gastrointestinal functions performed by the enteroendocrine cells, there is also the neural control performed by nerve cells present on the wall of the digestive tube, pancreas and biliary system, constituting the enteric nervous system (Furness 2000). This system contains two ganglion plexuses in the intestine, the myenteric and submucosal plexuses, where the majority of intrinsic nerve cells reside. Neurons in the enteric nervous system of the small intestine have been identified in terms of their morphologies, projections, primary neurotransmitters and physiological identifications. In this region there are 14 functionally defined neuron types, each with a characteristic combination of morphological, neurochemical and biophysical properties. Most neurons are characterized as sensorials (afferent), motors (efferent) and interneurons (Furness 2000). The nervous and endocrine systems jointly control intestinal movements, secretion of its glands and participate indirectly in the processes of nutrient digestion and absorption (Rodrigues et al. 2005).

The enteric and endocrine nervous systems are involved in many physiological processes and even in pathological processes of the digestive tract, which are essential to normal life (De Giorgio et al. 2000). Therefore, it is necessary to better understand the distribution of ganglions and endocrine cells dispersed along the small intestine of mammals.

Based on these factors, the objective of the present work was to quantify argyrophillic, argentaffin and insulin immunoreactive endocrine cells in the initial, mid and final regions of the duodenum, jejunum and ileum of opossums (Didelphis aurita) weighing more than 400 $\mathrm{g}$ (adults), and to quantify the ganglia of the submucosal and myenteric plexuses and nervous cells of ganglia in segments of the small intestine. Since regulation of events linked to digestion is performed by the integrated action of the nervous and endocrine systems, we verified that endocrine and nervous cells are somehow related to ganglia. Finally, we performed a descriptive analysis of several morphometric parameters of the mucous, submucous and muscle layers of the small intestine.

\section{METHODS}

Ten adult opossums, both male and female, from the species $D$. aurita were used in this experiment. The animals were captured between January and June 2007 at Viçosa, Minas Gerais State, Brazil. Hook traps were placed to capture the opossums using bates composed of pineapple and cotton impregnated with cod liver oil. The animals weighing more than $400 \mathrm{~g}$ (adults) were euthanized with a general anesthetic (sodium pentabarbital), followed by the administration of potassium chloride. The capture of these animals was authorized by IBAMA (license n. 10168-1) and the experiment was evaluated by the Ethics Commission of the Veterinary Department of the Federal University of Viçosa (process n. 56/2007).

Two fragments $\left(1 \mathrm{~cm}^{2}\right)$ were collected from the initial, mid and final regions of each intestinal segment per animal. They were fixed for $24 \mathrm{~h}$ in Bouin's liquid for staining by the Grimelius 
technique (Grimelius 1968), the direct immunoperoxidase technique (Sternberger 1979) and the H-E techniques (Bancroft and Stevens 1996), and in $10 \%$ buffered formalin for the modified Masson-Fontana technique (Barbosa et al. 1984). The fragments were then dehydrated, diaphanized, embedded in paraffin and sectioned $5 \mu \mathrm{m}$ width with the assistance of a manual rotating microtome (model Leica, RM2155). Each slide had four sections of the same fragment, each one being placed $30 \mu \mathrm{m}$ far from each other during microtomy. It produced a total of six slides for each region. Therefore, a total of 24 sections were analyzed. After removing the paraffin, the histological sections were hydrated and stained. The staining techniques aimed to identify and quantify argyrophillic cells (Grimelius), argentaffin cells (modified MassonFontana), insulin immunoreactive (IR) cells (direct immunoperoxidase), submucosal and myenteric ganglia and nervous cells (H-E techniques).

In the argyrophillic reaction (Grimelius technique), the silver salts in ammoniacal, aqueous or alcoholic solution bond to the cytoplasmic granules, being then reduced to silver metal by the exposure to an exogenous reducing substance. In the argentaffin reaction (modified Masson-Fontana technique), a reduction in the ammoniacal silver nitrate is a result of the reducing capacity of its cellular components (Rodrigues et al. 2005).

The antibodies used in the immunohistochemical technique were produced by the Bethyl laboratory, lot n. A90-117P-4, and the opossum pancreas was used as a positive control. Processing of the material was performed at the Laboratory of Structural Biology of the General Biology Department, Federal University of Viçosa.

Quantification of the argentaffin, argyrophillic and insulin immunoreactive cells was performed in six random fields of the mucosa sections, which were defined by the extension of the ocular micrometric scale coupled to a 10X ocular, equivalent to $300 \mu \mathrm{m}$ in extension and with an objective of 40X. Likewise we counted the nervous cells in the submucous and myenteric ganglia. The area of the mucosa was obtained from the average thickness multiplied by the extension of the micrometric scale. The average number of endocrine cells was registered for each $\mathrm{mm}^{2}$ of the mucosa layer, and likewise the average number of nervous cells in muscular and submucous layers. The mucous, submucous and muscle areas were obtained from its average thickness multiplied by the length of the micrometric scale.

For the quantification of submucosal and myenteric ganglia, a 10X objective was used, where six fields of submucous and muscular layers were studied, respectively. These fields were delimited by the extension of the ocular micrometer scale equivalent to $1000 \mu \mathrm{m}$ in extension. An average number of endocrine cells per $\mathrm{mm}^{2}$ of the mucous layer area was registered, as well as the number of submucosal and myenteric ganglia for each $\mathrm{mm}^{2}$ of submucous and muscular layers, respectively. The mucous, submucous and muscular areas were obtained by multiplying the average width by micrometric scale.

To verify differences in terms of the number of endocrine cells in the initial, mid and final regions of each segments, and the number of submucosal and myenteric ganglia between the intestinal segments (duodenum, jejunum and ileum), the Kruskal-Wallis test $(H)$ was employed. The possible relationship between the number of endocrine cells and submucosal and myenteric ganglia, and the number of endocrine and nervous cells was tested by a regression analysis $(P<0.05)$ where the $r s$ described in the tables represent the Spearman Coefficient.

\section{RESULTS}

The mucous layer of the small intestine of $D$. aurita generally consists of digitiform villosities in all three segments (Figure 1). In the mucous layer of the duodene there are intestinal glands or Brünner glands, and still a muscular layer. Several villi with multiple 
heads were found in all segments. The submucous layer with a connective tissue of mucous showed a lot of neurons, forming the Meissner or submucous plexus (Figure 2). The muscular layer also showed neurons of myenteric plexus (Auerbach plexus) (Figure 3). This layer was constituted by two layers of smooth muscles, an inner circular layer and other external longitudinal layer. The neurons of the myenteric plexus were located between these two layers.

Regarding the morphometry of the intestinal tube (Figure 1), the mucous layer had an average thickness of $508.93 \pm 177.69 \mu \mathrm{m}$; the average

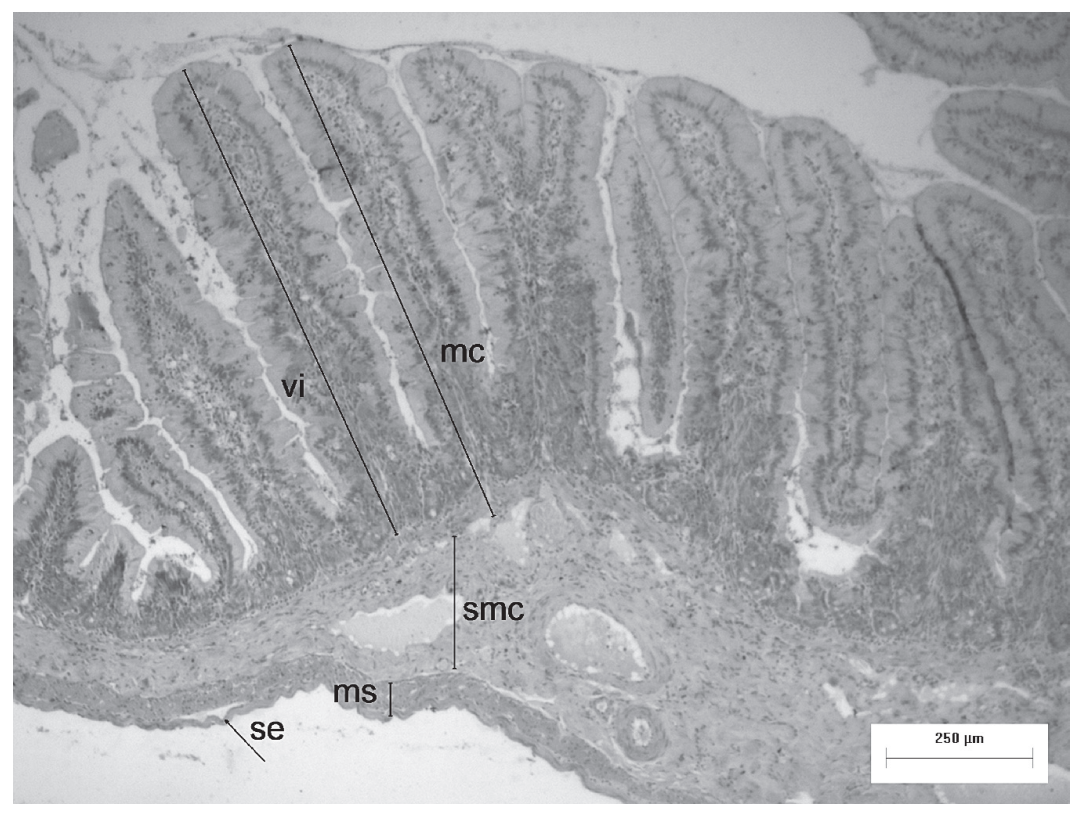

Figure 1 - Tube of the small intestine of $D$. aurita. vi-villus; mc-mucous layer; smc-submucous layer; ms-muscular; se-serous (H-E).

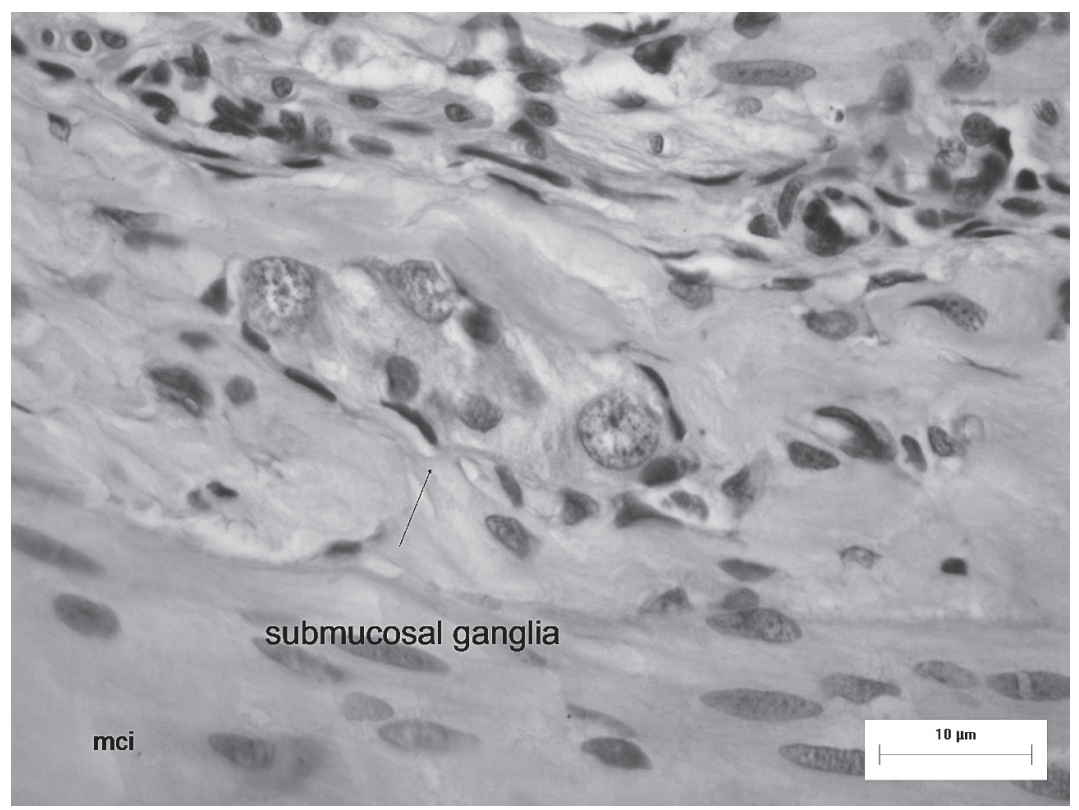

Figure 2 - Submucous nervous plexus in the small intestine of $D$. aurita. mci-inner circular muscular layer (H-E). 
height of villi was $395.40 \pm 170.59 \mu \mathrm{m}$; inner and external muscular layers had $146.47 \pm 78.05 \mu \mathrm{m}$; and the submucous layer $102.03 \pm 74.20 \mu \mathrm{m}$.

The endocrine cells (Figures 4 and 5) distributed along the digestive tube of $D$. aurita were located in the epithelium lining of the mucous and in the glandular epithelium interspersed with exocrine cells. They had a varied morphology despite most them seeming to be oval in shape. Two cell types were observed, one in which the cells reached the luminal surface (the open type), and the other presenting no continuity with the lumen (the closed type).

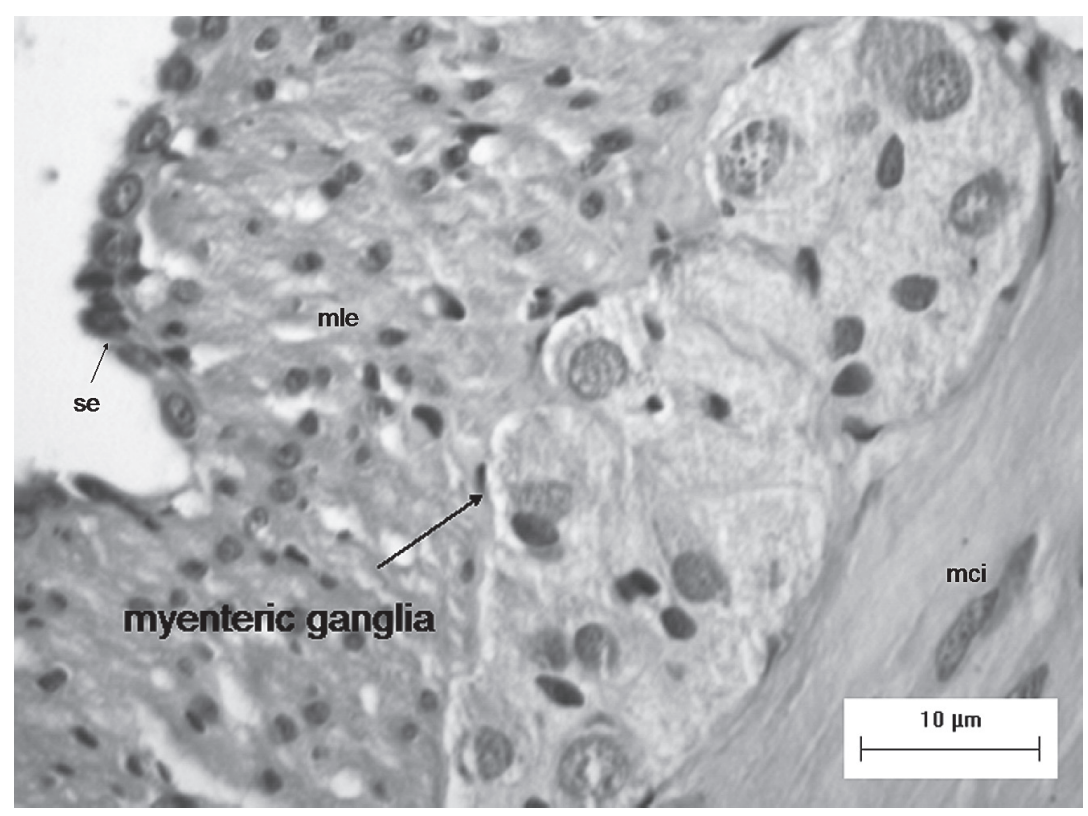

Figure 3 - Myenteric nervous plexus in the small intestine of $D$. aurita. mci-inner circular muscular layer; mle-external longitudinal muscular layer; se-serous (H-E).

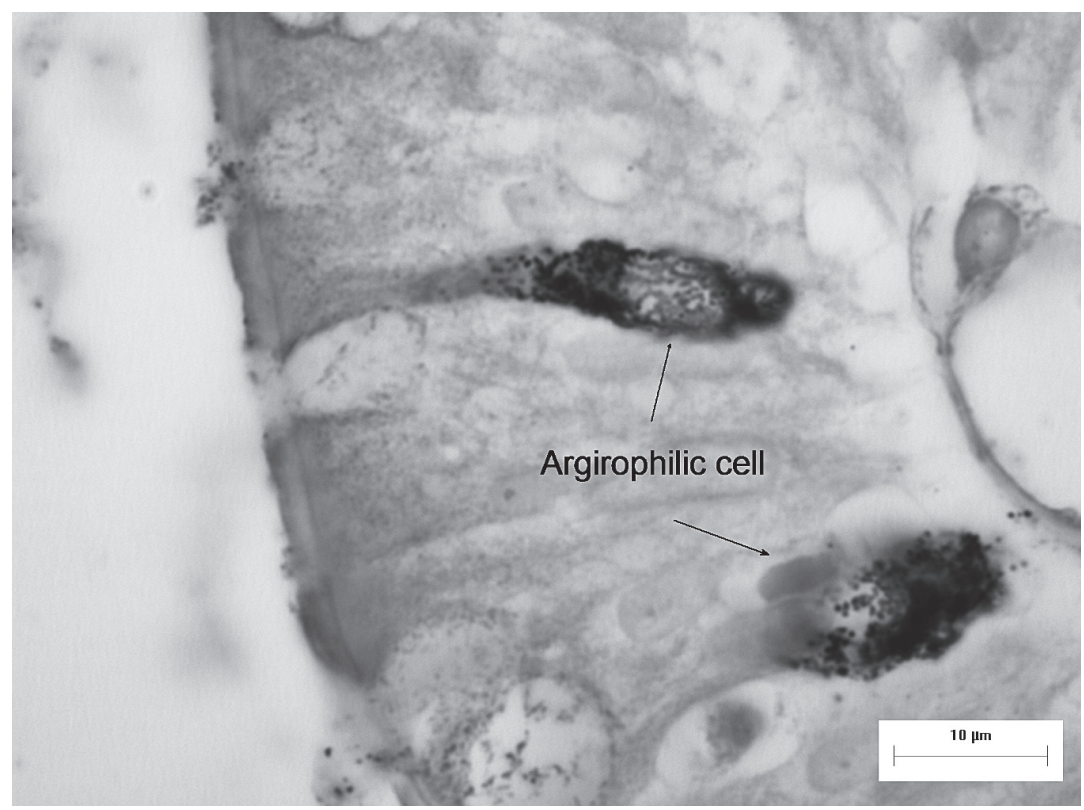

Figure 4 - Argirophilic endocrine cells in the mucous layer of the ileum of D. aurita (Grimelius technique). 


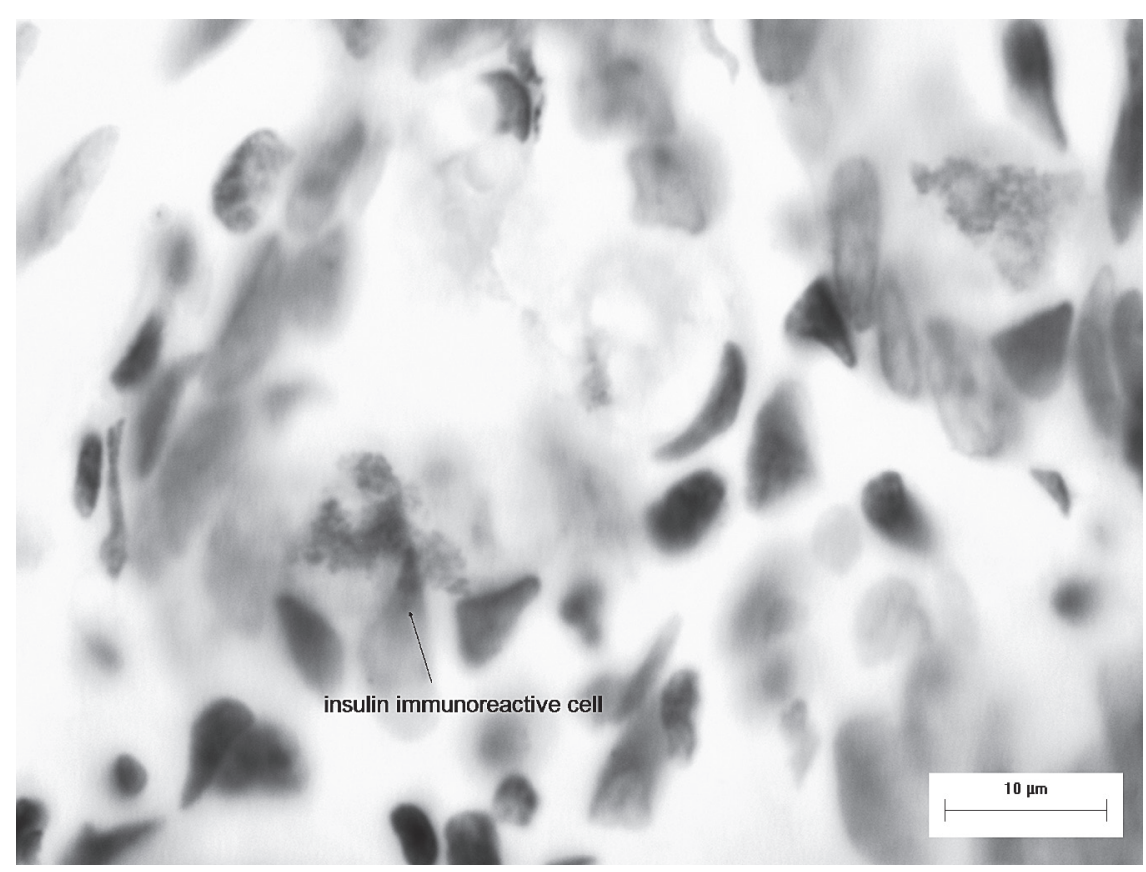

Figure 5 - Immunoreactive endocrine cells to insulin in the mucous layer of the ileum of $D$. aurita (Imunoperoxidase technique).

TABLE I

Number of endocrine and nervous cells and the submucosal and myenteric nervous ganglia in the small intestine of adult opossums.

\begin{tabular}{|c|c|c|c|c|c|c|c|}
\hline $1^{\mathrm{a}}$ & argyrophillic & argentaffin & Insulin I R & $2^{\mathrm{b}}$ & $\begin{array}{c}\text { Submucosal } \\
\text { ganglia }\end{array}$ & $\begin{array}{c}\text { Myenteric } \\
\text { ganglia }\end{array}$ & Nervous Cells \\
\hline $\mathrm{D}_{\mathrm{i}}$ & $61.11 \pm 13.38^{\mathrm{a}}$ & $17.63 \pm 7.14^{\mathrm{a}}$ & $0.86 \pm 0.51^{\mathrm{a}}$ & & & & \\
\hline $\mathrm{D}_{\mathrm{m}}$ & $65.82 \pm 16.93^{\mathrm{a}}$ & $15.36 \pm 7.13^{\mathrm{a}}$ & $0.56 \pm 0.42^{\mathrm{a}}$ & $\mathrm{D}$ & $5.49 \pm 2.60^{\mathrm{a}}$ & $5.79 \pm 1.42^{\mathrm{a}}$ & $29.36 \pm 10.06^{\mathrm{ab}}$ \\
\hline $\mathrm{D}_{\mathrm{f}}$ & $68.02 \pm 11.40^{\mathrm{a}}$ & $14.81 \pm 6.06^{\mathrm{a}}$ & $0.72 \pm 0.68^{\mathrm{a}}$ & & & & \\
\hline $\mathrm{J}_{\mathrm{i}}$ & $48.41 \pm 7.58^{\mathrm{ab}}$ & $10.18 \pm 4.26^{\mathrm{a}}$ & $0.71 \pm 0.65^{\mathrm{a}}$ & & & & \\
\hline $\mathrm{J}_{\mathrm{m}}$ & $54.71 \pm 11.56^{\mathrm{a}}$ & $10.78 \pm 3.68^{a}$ & $0.49 \pm 0.36^{\mathrm{a}}$ & $\mathrm{J}$ & $5.21 \pm 2.19^{\mathrm{a}}$ & $8.03 \pm 3.13^{\mathrm{a}}$ & $25.40 \pm 10.54^{\mathrm{a}}$ \\
\hline $\mathrm{J}_{\mathrm{f}}$ & $40.20 \pm 13.40^{\mathrm{b}}$ & $7.19 \pm 4.43^{\mathrm{a}}$ & $0.62 \pm 0.67^{\mathrm{a}}$ & & & & \\
\hline $\mathrm{I}_{\mathrm{i}}$ & $54.11 \pm 15.56^{\mathrm{a}}$ & $6.92 \pm 2.54^{\mathrm{a}}$ & $1.46 \pm 1.45^{\mathrm{a}}$ & & & & \\
\hline $\mathrm{I}_{\mathrm{m}}$ & $45.56 \pm 11.72^{\mathrm{a}}$ & $7.61 \pm 4.08^{\mathrm{a}}$ & $1.34 \pm 1.27^{\mathrm{a}}$ & I & $6.59 \pm 3.80^{\mathrm{a}}$ & $9.95 \pm 5.54^{\mathrm{a}}$ & $35.09 \pm 15.54^{b}$ \\
\hline $\mathrm{I}_{\mathrm{f}}$ & $51.36 \pm 18.57^{\mathrm{a}}$ & $5.98 \pm 4.43^{\mathrm{a}}$ & $0.96 \pm 1.04^{\mathrm{a}}$ & & & & \\
\hline
\end{tabular}

Endocrine and nervous cells per $\mathrm{mm}^{2}$ (average \pm standard deviation) and the submucosal and myenteric ganglia (average \pm standard deviation) per $\mathrm{mm}^{2}$ of the submucous and muscular layers. ( $1^{\mathrm{a}}$ : regions) $\mathbf{D}, \mathbf{J}$ and $\mathbf{I}$ represent the duodenum, jejunum and ileum segments, respectively. ( $2^{\mathrm{b}}$ : segments) Lower case letters $\mathbf{i}, \mathbf{m}$ and $\mathbf{f}$ represent, in this order, the initial, mid and final regions of each segment. The average followed by the same letter, in the same column, does not differ among themselves by the Kruskal-Wallis test at the significance level of $5 \%(n=10)$. 
TABLE II

Comparative analysis of the number of endocrine cells between the regions of the mucous layers in the duodenum, jejunum and ileum of adult opossums.

\begin{tabular}{cccc}
\hline & $\begin{array}{c}\text { Initial, Mid and } \\
\text { Final Duodenum }\end{array}$ & $\begin{array}{c}\text { Initial, Mid and } \\
\text { Final Jejunum }\end{array}$ & Initial, Mid and Final Ileum \\
\hline Argyrophillic & $H=1.0 ; P=0.59$ & $H=6.82 ; P=0.03$ & $H=1.40 ; P=0.49$ \\
Argentaffin & $H=0.96 ; P=0.61$ & $H=3.83 ; P=0.14$ & $H=1.89 ; P=0.38$ \\
Insulin IR & $H=2.04 ; P=0.36$ & $H=0.23 ; P=0.88$ & $H=0.95 ; P=0.62$ \\
\hline
\end{tabular}

Kruskal-Wallis test. $g \mathrm{l}=2$. The adopted significance level was $5 \%(\mathrm{n}=10)$.

TABLE III

Relationship between the number of enteroendocrine cells and submucous and myenteric ganglia, and endocrine and nervous cells in the duodenum, jejunum and ileum of adult opossums.

\begin{tabular}{clll}
\hline & Argyrophillic Cells & Argentaffin Cells & Insulin IR Cells \\
\hline Submucosal ganglia & $r s=0.12 ; P=0.51$ & $r s=0.20 ; P=0.27$ & $r s=0.19 ; P=0.29$ \\
Myenteric ganglia & $r s=-0.34 ; P=0.06$ & $r s=-0.16 ; P=0.37$ & $r s=-0.19 ; P=0.30$ \\
Nervous cells & $r s=0.03 ; P=0.79$ & $r s=0.07 ; P=0.53$ & $r s=0.20 ; P=0.05$ \\
\hline
\end{tabular}

Regression Analysis. The adopted significance level was 5\% ( $\mathrm{n}=10)$.

No variation was observed between different endocrine cells in the initial, mid and final regions of the segments, except for argyrophillic cells in the jejunum (Tables I and II). Most of them presented an oval shape. Open and closed types of endocrine cells were observed interspersed with exocrine cells.

Nerve cells were observed in groups and also isolated, both in the submucous layer and between the muscular layers. The number of submucosal $(H=$ $0.54 ; \mathrm{df}=2 ; P=0.76)$ and myenteric $(H=5.44 ; \mathrm{df}=$ 2; $P=0.06)$ ganglia did not vary between all small intestine segments of $D$. aurita (Table I). The number of nervous cells varied only between jejunum and ileum $(H=8.70 ; \mathrm{df}=2 ; P=0.01)$ (Table I). In average, 17.29 submucosal ganglia/ $/ \mathrm{mm}^{2}$ were encountered in the submucous, and 23.77 myenteric ganglia/ $/ \mathrm{mm}^{2}$ in the muscular region. The myenteric plexus was apparently greater than that of the submucous.

There is no relationship between the number of ganglia and nervous cells, and endocrine cells in different segments of the small intestine of $D$. aurita $(P>0.05)$ (Table III).

\section{DISCUSSION}

The difference among duodenum, jejunum and ileum of $D$. aurita was similar to that described for rodents (Altmann and Leblond 1970, Allogninouwa et al. 1996), pigs (Mitjans and Ferrer 2004) and capybaras (Velásquez et al. 2003, Rodrigues et al. 2006). The duodenum was highlighted by the presence of Brünner glands in the submucous layer. These glands were not observed in the submucous layer of the jejunum and ileum. The ileum was identified by the presence of associated lymph nodes (Peyer dishes) for all mucous layer, as well by submucous layer.

In descending order, the argyrophillic cells were more numerous than argentaffin cells, and argentaffin than insulin immunoreactive cells. Such results can be explained by the employed technique since argentaffin reactions appears only in enterochromaffin cells, while the argyrophillic reaction occurs in nearly all enteroendocrine cells, except in cholecystokinin, somatostatin and insulin-producing cells (Polak et al. 1993). The 
immunohistochemical technique used to stain the insulin immunoreactive cells is more specific than those used for other cells. This is due to the fact that the employment of monoclonal antibodies increases the sensibility of this method.

In our work, insulin immunoreactive cells were found insolated in intestinal crypts and villi. Kendzierski et al. (2000) encountered intracellular immunoreactivity to insulin in glandular cells of the stomach and the colon of rats, but not in the small intestine. Contrarily, Coutinho et al. (1984) observed a positive insulin staining in the brush border and in some cells isolated in segments near the small intestine of adult opossums (Didelphis albiventris), although no evidence was observed in the mid and distal segments. Likewise, Bendayan and Park (1991) located extrapancreatic islets between the duodenum crypts and the muscle layer of the mucosa in rats. These islets were restricted to the duodenum region and crossed by the final portion of the bile duct before its opening in the intestinal lumen. The islets were surrounded by conjunctive tissue and exhibited no direct contact with the epithelial cells of the ducts and crypts. Ito et al. (1988) also encountered a small number of insulin immunoreactive cells in the pyloric antrum and duodenum of pigs between 32 and 41 days old.

Pancreatic insulin reduces glucose in blood, increases the deposit of glycogen in the muscles and the metabolic use of the glucose, while enteral insulin controls the intestinal motility (Kendzierski et al. 2000).

Studies with endocrine cells distributed along the digestive tube of mammals generally refer only to those located in one of the segment regions, therefore disconsidering the initial, mid and final regions of each segment (Krause et al. 1989, Takagi et al. 1990, Fonseca et al. 2002). It was believed that differences in the number of endocrine cells can be encountered between regions of the small intestine segments of $D$. aurita. However, this fact was not statistically proven in this work.
Ganglia of the submucosal plexus were concentrated near the muscularis mucosa and myenteric ganglia located between the circular internal layer and the longitudinal external layers together with nerve clusters as related to eutherian mammals (Young et al. 1993, Brehmer et al. 1994, Liberti et al. 1994, 1998). The plexuses were prominent, being the myenteric one apparently greater than that of submucous, that is, with a greater population of neuron bodies, similar to those encountered in the small intestine of the ginea-pig (Liberti et al. 1994). According to Bressan et al. (2004), the greater size of the myenteric ganglia reflects its importance in the intestinal motility control. The propulsion and mixing movements of the small intestine include an assembly of neurons in the plexus. In the small intestine of pigs, the contraction of a single $10 \mathrm{~mm}$ unit includes roughly 6,500 intrinsic primary afferent neurons in the myenteric ganglion, 1,200 ascending interneurons, 3,000 descending interneurons, 4,000 inhibitory motor neurons of the circular musculature and 3,000 excitatory motor neurons for the circular muscle (Clerc et al. 1998, Kunze and Furness 1999).

The clusters formed by the neuron bodies had varying sizes and forms in the two plexuses. Nerve cells were observed isolated, not grouping together in both plexuses. Leaming and Cauna (1961) also encountered isolated nerve cells and grouped nerve cells in the duodenum and jejunum of cats, being that the myenteric plexus of the jejunum contains more nerve cells forming groups than the myenteric plexus of the duodenum, with an average of 37 cells $/ \mathrm{mm}^{2}$ in the jejunum and 12.17 cells $/ \mathrm{mm} 2$ in the duodenum.

Myenteric and submucosal plexuses can differ between organs regarding the function of their motility standards, as well as the shape and number of neurons within the same organ, and differ between species (Tafuri and Brenner 1967, Christensen 1988). For example, the small intestine of sheep contains 11 times more 
myenteric neurons than the one of pigs, and approximately 80 times more than that of mice (Gabella 1987).

Our data indicate a greater quantity of myenteric ganglia (23.77 ganglia/ $\mathrm{mm}^{2}$ ) when compared to those of submucous (17.29 ganglia/ $\left./ \mathrm{mm}^{2}\right)$ in the small intestine of $D$. aurita. Rodrigues (unpublished data) also obtained this relation, in which in the small intestine of capybaras, 2.29 myenteric ganglia were found in the muscular layer and 0.69 submucosal ganglia in the submucous layer, both with $1.2 \mathrm{~mm}$ length. There was no difference between the quantity of myenteric and submucosal ganglia in the segments in the small intestine of capybaras. However, it seems that a greater quantity of ganglia was found in the ileum. According to this author, since the number of ganglia is more frequent in portions with greater motility, it is possible that there exists no significant difference among the duodenum, jejunum and ileum of capybaras, as well as the capacity of muscle peristalsis. The myenteric ganglia control peristaltic movements of the intestine and the submucous, as well as participate in the innervation of the muscle layer, regulate the gastrointestinal secretion and blood flow (Hens et al. 2002).

Neuro-histological studies have been carried out on the myenteric plexus of the duodenum and jejunum of adult cats using silver method (Leaming and Cauna 1961). In this study, these authors found 122 and 30.7 cells $/ \mathrm{mm}^{2}$ in the duodenum and jejunum, respectively. In our work, we found 29.36 and 25.40 cells $/ \mathrm{mm}^{2}$ in the duodenum and jejunum, respectively. These differences probably occurred in the number of plexuses analyzed. We investigated two plexuses (submucosal and myenteric), while Leaming and Cauna (1961) have analyzed only the myenteric plexus.

Polak et al. (1993) reported some similarities between endocrine cells and enteric nerve cells, such as the presence of morphologically similar secretion granules, the presence of a sensorial and a transmitter part that liberates granules to the synaptosomal area and vascular pole. However, the peptides liberated by the nerve cells do not integrally meet the criteria for conceptual harmony, therefore employing the peptide-regulator term. A large portion of these peptides present a paracrine signaling effect locally stimulating neighboring cells, although they can interact with receptors and transform intracellular signals in other ones similar to those produced by circulating hormones (Santos and Zucoloto 1996). In the intestine, regulatory peptides can be encountered in the ganglia cells, nerve fibers and endocrine cells.

Immunohistochemical and molecular biology studies have revealed functional interactions between endocrine and neuronal cells (Delellis and Dayal 1992). However, the present study did not demonstrate this relationship in the morphometric field. We did not identify any relationship between the number of endocrine cells and submucous nervous and myenteric ganglia, and between endocrine and nervous cells of the opossum's small intestine. Bressan et al. (2004) who did not find any relationship between the number of endocrine cells and submucous and myenteric nervous ganglia of the caecum of capybara. Various techniques can be used in the identification of endocrine and ganglion cells, including histochemical (Masson-Fontana, Grimelius, Servier-Munger, Hellerstrom-Hellman) and immunocytochemical utilizing humoral and non-humoral markers (membrane proteins, enzymes and acid glycoproteins). Therefore, other techniques should probably be employed to confirm the quantitative interrelationship between the endocrine and nerve cells studied in this work.

\section{ACKNOWLEDGMENTS}

The authors would like to thank to many colleagues who gave important contributions to the manuscript. The current research was funded by Conselho Nacional de Desenvolvimento Científico e Tecnológico (CNPq, Edital Universal 02/2006). 


\section{RESUMO}

Os sistemas nervoso e endócrino controlam integradamente os movimentos intestinais, a secreção de suas glândulas e também participam dos processos de digestão e absorção de nutrientes. Portanto, o objetivo central deste estudo foi verificar a existência de uma possível relação entre o número de células nervosas e gânglios dos plexos submucosos e mioentéricos e o número de células endócrinas no intestino delgado de adultos de $D$. aurita. As técnicas de coloração utilizadas foram Grimelius, Masson-Fontana modificada, imunoperoxidase direta e H-E. As células endócrinas argirófilas, argentafins e imunorreativas à insulina não variaram numericamente entre as regiões inicial, média e final do duodeno, jejuno e íleo $(P>0,05)$, exceto as células argirófilas no jejuno $(P<0,05)$. Nenhuma relação numérica foi verificada entre o número de gânglios nervosos e células endócrinas, e também entre células nervosas e endócrinas. Nós recomendamos o emprego de novas técnicas imunohistoquímicas para confirmar a correlação numérica entre os sistemas nervoso e endócrino no intestino delgado. A morfologia e a distribuição das células endócrinas e dos gânglios nervosos estudados foram similares àqueles encontrados em mamíferos eutérios.

Palavras-chave: células argirófilas, células argentafins, células endócrinas, gânglios, insulina.

\section{REFERENCES}

Allogninouwa T, AGBA KC, Agossou E AND KpodeKon M. 1996. Anatomical, histological and functional specificities of the digestive tract in the male Grasscutter (Thryonomys swinderianus, Temminck 1827). Anat Histol Embryol 25: 15-21.

ALTMANN GG AND LEBLOND CP. 1970. Factors influencing villus size in the small intestine of adult rats as revealed by transposition of intestinal segments. Am J Anat 127: 15-36.

BANCROFT JD AND STEVENS A. 1996. Theory and practice of histological techniques. New York: Churchill Livingstone. USA, $766 \mathrm{p}$.

Barbosa AJA, CAStro LPF AND Nogueira AMF. 1984. A simple and economical modification of the MassonFontana method of staining melanin granules and enterochromaffin cells. Stain Technol 59: 193-196.
Barbosa AJA, Nogueira JC, Penna FJ and Polak JM. 1987. Distribution of enteroglucagon- and polypeptide YY-immunoreactive cells in the gastrointestinal tract of the white-belly opossum (Didelphis albiventris). J Histoch 88: 37-40.

BENDAYAN M AND PARK I-S. 1991. Presence of extrapancreatic islets of Langerhans in the duodenal wall of the rat. Diabetologia 34: 604-606.

BREHMER A, STACH W AND AdDICKS K. 1994. Fine Structural Distinction between Ganglia of the Outer and Inner Submucosal Plexus in Porcine Small Intestine. Acta Anat 151: 188-193.

Bressan MS, Fonseca CC, Menin E ANd PaUla TAR. 2004. Identificação e quantificação de gânglios nervosos, células argentafins, argirófilas e imunorreativas à serotonina no ceco de capivara (Hydrochoerus hydrochaeris). Rev Ceres 51: 29-739.

CHRISTENSEN J. 1988. The forms of argyrophilic ganglion cells in the myenteric plexus throughout the gastrointestinal tract of the opossum. J Auton Nerv Syst 24: 251-260.

ClerC N, Furness JB, Li ZS, Bornstein JC AND KunZE WAA. 1998. Morphological and immunohistochemical identification of neurons and their targets in the guineapig duodenum. Neuroscience 86: 679-694.

Coutinho HB, SEwel HF AND Coutinho VB. 1985 Immunocytochemical demonstration of insulin in the mesonephros and metanephros of the brazilian opossum Didelphis albiventris. Anat Anz Jena 159: 97-103.

Coutinho HB, Sewel HF, SMith DI, Coutinho VB AND PINHEIRO PBN. 1984. Demonstration of insulin in the pancreas of the Didelphis albiventris (Opossum) by immunocytochemical techniques. Anat Anz Jena 157: 167-175.

De Giorgio R, Stanghellini V, Barbara G, Corinaldesi R, De Ponti F, TONIni M, BASSOTI G AND STERnini C. 2000. Primary enteric neuropathies underlying gastrointestinal motor dysfunction. Scand J Gastroenterol 35: 114-122.

DELELLIS RA AND DAYAL Y. 1992. Neuroendocrine system. In: STERNBERG SS (Ed), Histology for pathologists. New York: Raven Press, USA, p. 347-362.

DEVASKar SU, Singh BS, CARNAGHI LR, RAJAKUMAR PA AND GIDDINGS SJ. 2002. Insulin II gene expression in rat central nervous system. Regul Pept 48: 55-63.

FonsecA CC, NOGUEIRA JC AND BARBosA AJA. 2002. Argyrophilic and Glucagon-Immunoreactive cells in the ileum and colon of the developing opossum Didelphis albiventris (Marsupialia). Cells Tissues Organs 170: 20-33.

FURNESS JB. 2000. Types of neurons in the enteric nervous system. J Auton Nerv Syst 81: 87-96.

GABELLA G. 1987. The number of neurons in the small intestine of mice, guinea-pigs and sheep. Neuroscience 22: 737-752.

GRIMELIUS L. 1968. A silver nitrate for $\alpha 2$ cells in human pancreatic islets. Acta Soc Med Upsal 73: 243-270.

GRIMELIUS L AND WILANDER E. 1980. Silver stains in the study of endocrine cells of the gut and pancreas. Investig Cell Pathol 3: 3-12. 
Hens J, Gajda M, Scheuermann DW AND AdRiaEnSEn D. 2002. The longitudinal smooth muscle layer of the pig small intestine is innervated by both myenteric and submucous neurons. Histochem Cell Biol 117: 481-492.

Ito H, Hashimoto Y, Kitagawa H, Kon Y AND Kudo N. 1988. Ontogeny of gastroenteropancreatic (GEP) endocrine cells in mouse and porcine embryos. Jap J Vet Sci 50: 99-110.

Kendzierski KS, Pansky B, Budd GC and Saffran M. 2000. Evidence for biosynthesis of preproinsulin in gut of rat. Endocrine 13: 353-359.

Krause WJ, Yamada J And CutTs H. 1985. Quantitative distribution of enteroendocrine cells in the gastrointestinal tract of adult opossum, Didelphis virginiana. J Anat 140: 591-605.

KraUSE WJ, YAMADA J AND CUTTS H. 1989. Enteroendocrine cells in the developing opossum small intestine and colon. J Anat 162: 83-96.

KUNZE WAA AND FuRNESS JB. 1999. The enteric nervous system and regulation of intestinal motility. Annu Rev Physiol 61: 117-142.

LEAMING DB AND CAUNA N. 1961. A qualitative and quantitative study of the myenteric plexus of the small intestine of the cat. J Anat 95: 160-168.

LIBERTI EA, GASPAR LP, CARVALHO CAF, FUJIMURA I AND SOUZA RR. 1998. A morpho-quantitative study of the myenteric ganglia throughout the human digestive tract. Rev Hosp Clin Fac Med Univ 53: 55-60.

Liberti EA, QueIroz LM, Popeu E, Perito MAM, MinARELli AM, Moraes JOR AND SOUZA RR. 1994. A quantitative and comparative study of the ganglionic neurons in the myenteric and submucous plexuses of the small intestine, and in the intramural plexus of the gall bladder of the ginea-pig. Rev Bras Cienc Morfol 11: 106-114.

MeImAridis DG, Morse DE, PANsKY B AND Budd GC. 2003. Insulin immunoreactivity in the fetal and neonatal rat retina. Neurosci Lett 118: 116-119.

MitJAns M AND FERRER R. 2004. Morphometric study of the guinea pig small intestine during development. Microsc Res Techn 63: 206-214.
POLAK JM, Bishop AE, BARBOSA AJA AND BLOOM SR. 1993. Hormônios gastrointestinais. In: DANI R AND CASTRO LP (Eds), Gastroenterologia Clínica. Rio de Janeiro: Guanabara-Koogan, Brasil, p. 1446-1465.

Rodrigues SS, FonseCA CC AND NEves MTD. 2005. Células endócrinas do sistema gastropancreático: conceitos, distribuição, secreções, ação e controle. Arq Cienc Vet Zool 8: 171-180.

Rodrigues SS, Fonseca CC, PAula TAR and Peixoto JV. 2006. Aspectos biométricos corporais e do intestino delgado da capivara Hydrochoerus hydrochaeris Linnaeus, 1766 (Mammalia, Rodentia, Hydrochaeridae). Biotemas 19: 79-86.

SANTOS GC AND ZuCOLOTO S. 1996. Células endócrinas gastrointestinais: breve histórico e principais métodos de identificação à microscopia óptica. Arq Gastroenterol 33: 36-44.

STAHLER MS, PANSKY B AND BUdD GC. 1988. Immuno cytochemical demonstration of insulin-like immunoreactivity in the rat prostate gland. Prostate 13: 189-198.

STERNBERGER LA. 1979. Immunocytochemistry. New York: J Wiley \& Sons, USA, $104 \mathrm{p}$

TAFURI WL AND BRENNER Z. 1967. Lesões dos plexos de Meissner e de Auerbach do intestine de camundongo albino na fase crônica da tripanossomíase cruzi experimental. Rev Inst Med Trop 9: 149-154.

Takagi C, Yamada J, Krause WJ, Kitamura N and YAMASHITA T. 1990. An immunohistochemical study of endocrine cells in the proximal duodenum of eight marsupial species. J Anat 168: 49-56.

Velásquez JC, Fonseca CC, Menin E and Paula TAR. 2003. Estudo histológico do intestino delgado de capivaras adultas (Hydrochoerus hydrochaeris). Arq Ciência Vet Zool 6: 21-25.

Young HM, Furness JB, SEWELl P, BurCher EF AND KANDIAH CJ. 1993. Total numbers of neurons in myenteric ganglia of the guinea-pig small intestine. Cell Tissue Res 272: 197-200. 